\title{
Wall Painting Decoration from the North-West Church in Hippos-Sussita of the Decapolis
}

\author{
JULIA BURDAJEWICZ
}

\begin{abstract}
Excavations in the North-West Church yielded numerous fragments of plain and painted wall plaster, which suggest that the entire interior of the church was plastered, and in large part, decorated with wall paintings. The majority of painted remains were discovered in the martyrion chapel and in the diakonikon. This paper describes the findings and addresses the following questions: to what extent was the church painted; what did the paintings represent; were these paintings aniconic; what are the characteristic features of the technique of execution of these paintings; do these paintings belong to a single phase of decoration of the church?
\end{abstract}

Keywords: Hippos-Sussita, Early Byzantine period, churches, wall painting, Palaestina Secunda, pre-iconoclastic period

Julia Burdajewicz, Faculty of Conservation and Restoration of Works of Art, Academy of Fine Arts in Warsaw, Warszawa; julia.burdajewicz@asp.waw.pl

A great number of fragments of wall plaster found in debris or still fixed to the walls as well as the character of the masonry of the North-West Church ${ }^{1}$ in Hippos-Sussita indicates that the interior of the church was entirely covered with plaster (Fig. 1). The walls of the basilica were erected with the use of random building material available to its constructors; neat basalt and limestone ashlars, reused basalt column drums and marble bases, pieces of cornices and other elements from dismantled Hellenistic and Roman-era buildings of Sussita were used in conjunction with crude and undressed fieldstones and rubble. Such variety of masonry materials not only required a significant amount of mortar to bind all elements together, but also must have been concealed and protected from deterioration under a layer of plaster. Finally, plastering of the walls doubtlessly enhanced the appearance of the interior and lighted it up. Archaeological evidence from the North-West Church is not,

\footnotetext{
${ }^{1}$ The North-West Church is a large basilica with a pastophorion, a martyrion and two wings housing a diakonikon and a wine press. It is dated to the sixth-mid-eight century. For more information see: Młynarczyk, Burdajewicz 2013.
} 


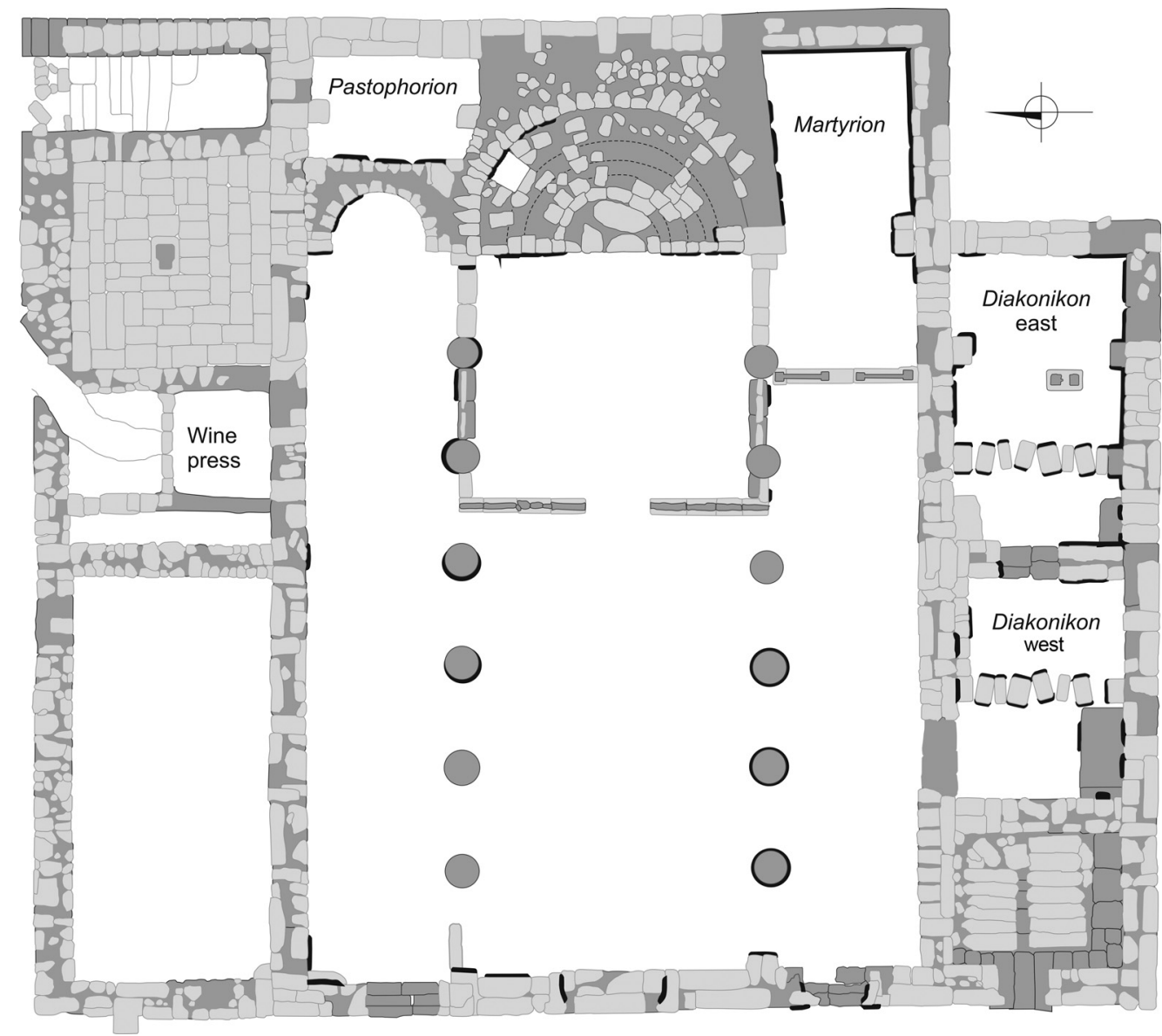

1. The plan of the North-West Church with locations of plaster found in situ marked with black color (Drawing: M. Burdajewicz).

however, limited to plain plaster. Patches of painted plaster were found still attached to some of the collapsed ashlars and a significant number of painted plaster fragments were recovered from debris throughout the church.

\section{THE NAVE}

Excavations in the nave of the church yielded a few fragments of plain white plaster surviving on the steps of the synthronon, in the apse, as well as on the limestone chancel screen. A handful of small red and black colored pieces were recovered from the debris. However, it was only after the first rainfall following the excavations that any significant discovery could be made. Plaster surviving on several columns turned out to be painted. It appears that the shafts were plain white with $2-3 \mathrm{~cm}$ wide green winding strands arranged in a vertical direction (Fig. 2). A couple of basalt capitals retain red plaster on the echinus 
2. Remains of painted plaster on one of the columns in the North-West Church with traces of green winding strands (Phot. J. Burdajewicz).

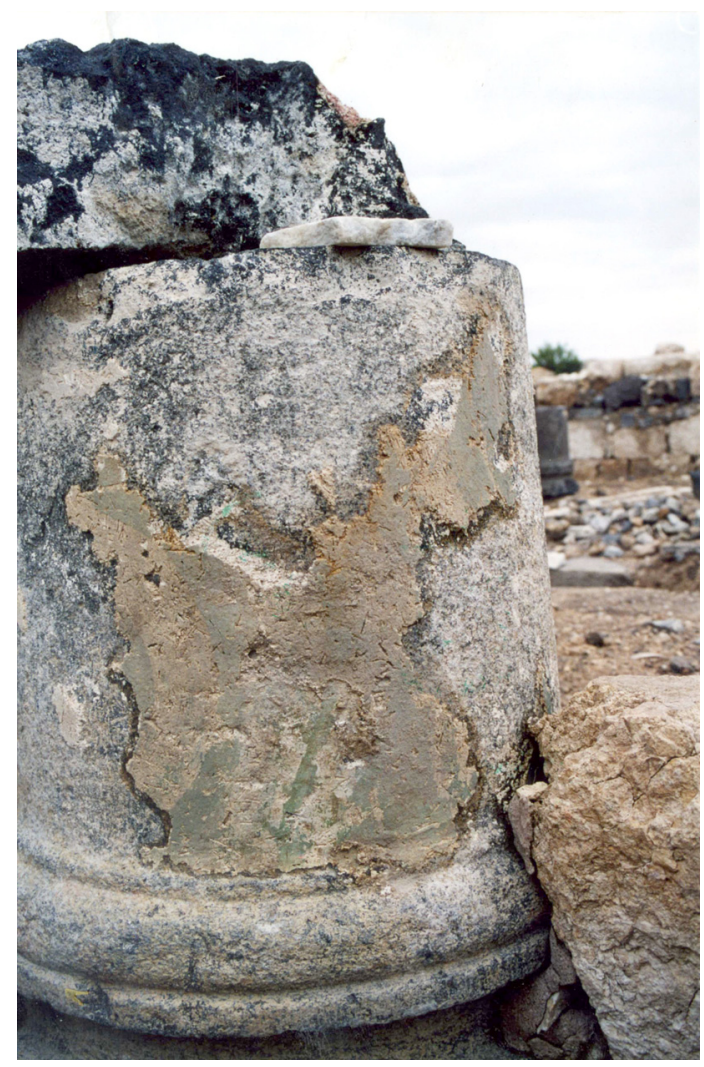

in between the volutes and green plaster on the uppermost part of the column's shaft. These green traces were initially interpreted as a wreath of laurel-like leaves, ${ }^{2}$ but surviving remains are in fact too fragmentary to confirm such an interpretation. The bases of the columns were made of white marble (reused from earlier buildings) and hence it is unlikely that they were plastered, especially because the smooth character of marble surface would render plastering very difficult.

\section{THE AISLES}

Remains of plain white plaster were found on the masonry of the northern aisle and its apse as well as on the chancel screen between the aisle and the presbytery. A number of pieces of painted plaster were collected along the northern wall of the northern aisle. They represent white and red bands and unidentified motifs in either red or green, against a yellow background. The excavators noted upon discovery that the decoration appears to have been arranged mainly in bands or rectangular panels, but some fragments allow one

\footnotetext{
${ }^{2}$ Młynarczyk, Burdajewicz 2003: 28.
} 
also to distinguish some curved motifs. ${ }^{3}$ Additionally, ten fragments of plaster with Greek letters painted red directly on a white background were also recovered from the debris of the north aisle. The letters are about $3 \mathrm{~cm}$ tall. They are unfortunately too fragmentary to be assembled and interpreted.

A few blocks in the western wall of the pastophorion retain patches of plaster painted in red and yellow. However, it is not certain whether these murals were executed in this room or in an earlier structure, from which the reused basalts stones come from. The latter supposition seems plausible since no pieces of painted plaster were found in the debris of this room. ${ }^{4}$

Interestingly, the south aisle yielded no fragments of painted plaster. It is impossible to determine whether painted decoration did not survive or did not exist there, at least in the final phase of the occupation of the church. A few plain white fragments of plasters were found in situ only on the door jambs of the entrance to the south aisle from the atrium and on its lintel. Given the construction of the walls and general aesthetic reasons, it seems logical though that the interior wall of this aisle also had to be plastered.

\section{MARTYRION}

The vast majority of painted plasters found in the North-West Church come from the martyrion chapel, which is located in the eastern end of the south aisle. ${ }^{5}$ Numerous pieces of painted plaster were recovered from debris, some were found fixed to collapsed basalt blocks, others survived in situ. Among them several types of decoration can be distinguished.

\section{Decoration of the ArchWAY}

The entrance to the martyrion chapel led under an archway constructed of basalt blocks. Two piers of the archway were crowned with basalt imposts reused from a Roman-era building. The imposts, decorated with a dentils and ovolo motif, were most likely segments of a cornice. The original carved decoration was, however, completely covered and obscured with thick plaster painted red. ${ }^{6}$

A number of basalt voussoirs which collapsed from the archway were found in the debris. They are neatly dressed, some of them with a visibly concave intrados surface. All of them are $70 \mathrm{~cm}$ long, their height, however, ranges from 21 to $35 \mathrm{~cm}$; the width of the blocks varies between 21 and $25 \mathrm{~cm}$. It appears that the voussoirs also come from an earlier building and were reused during construction of the arch. Noteworthy is the fact that only one of their faces is dressed to a high degree, whereas the other one is just roughly hewn. This may indicate that they came from a vault or from an arch which was more than one course thick; the roughly hewn side of each block would be the interior one. Six

\footnotetext{
${ }^{3}$ Młynarczyk, Burdajewicz 2001: 8 .

${ }^{4}$ Młynarczyk, Burdajewicz 2001: 10.

${ }^{5}$ Rądkowska 2004: 76-79.

${ }^{6}$ Młynarczyk, Burdajewicz 2002: 21.
} 
a

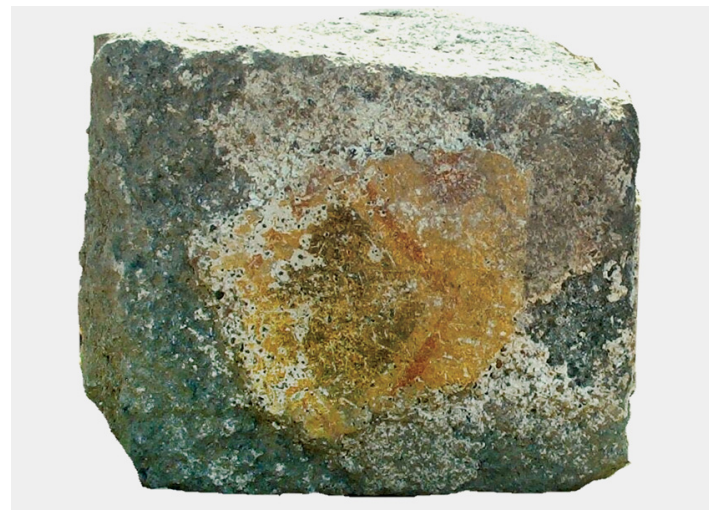

b

3a. One of the decorated (green rhombus in a red contour) voussoirs from the archway leading to the martyrion; b. a voussoir from the archway leading to the martyrion upon discovery (Phot. J. Burdajewicz).
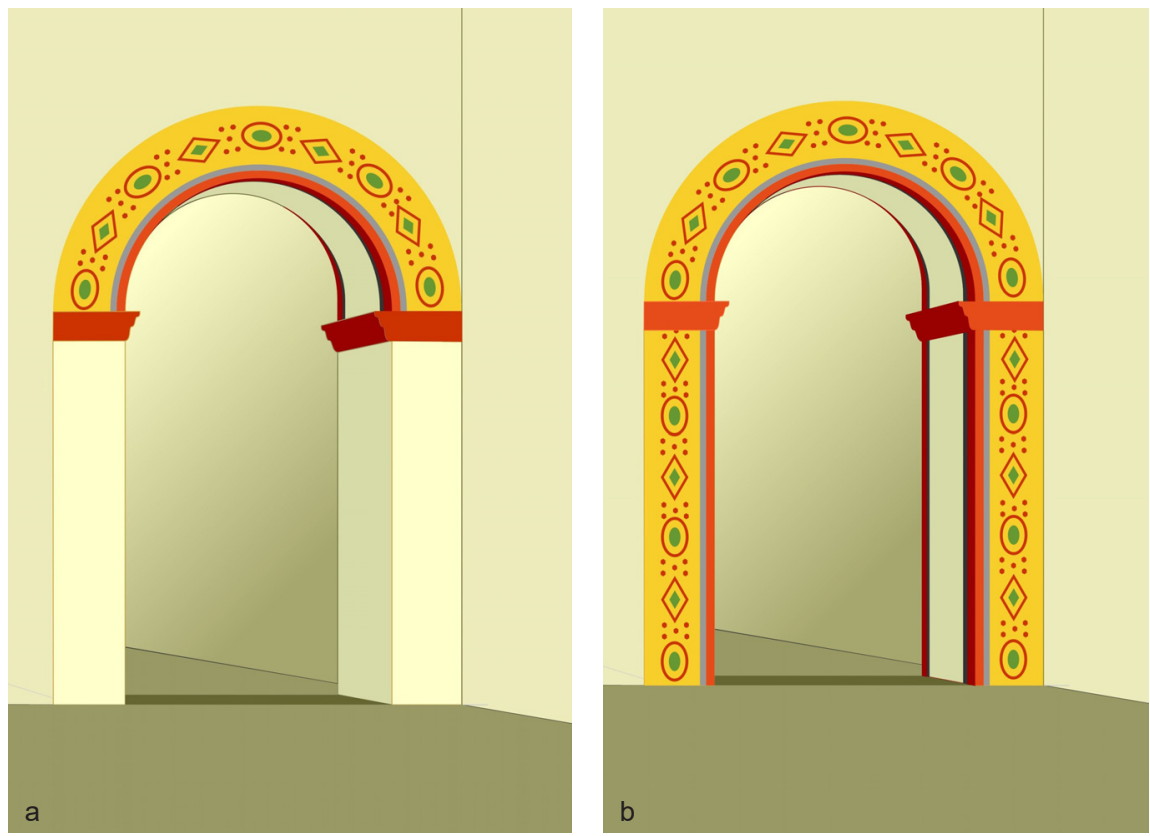

4a. Graphic reconstruction of the 'rhombi and ovals' decorating the archway to the martyrion; b. the same motif decorating also the piers of the arch (Drawing: J. Burdajewicz). 
of the recovered voussoirs retained plaster on their intrados and on the dressed faces. The plaster on the intrados surface is generally plain white with only one of the blocks featuring a trace of a top of a round yellow shape in the center of a white field. The ridges are decorated with a red vertical band (folded over the ridge) and a faded black stripe next to it. The faces of the blocks are decorated with simple geometric shapes: green ovals and rhombi with red contours placed against a yellow background. The ovals and rhombi were arranged alternately, separated from each other with sets of five red dots (Fig. 3a).

One of the voussoirs was found virtually in situ, only slid down from the springer of the arch (Fig. 3b). Its position indicates that the neatly dressed face of the block with 'rhombi and ovals' decoration faced the aisle. This decorative pattern appears on the 'even' faces of other blocks, while very little painted plaster survives on their rear sides. It seems logical that when constructing the arch, the voussoirs were arranged with their neatly dressed faces (that is, well-fitted to plastering and painting) facing the aisle, while the rough ends were directed towards the interior of the chapel. This would indicate that the western face of the arch was decorated with an ornament of alternating rhombi and ovals separated with sets of five red dots (Fig. 4a). Both ridges of the arch were decorated with vertical black and red bands. However, the remains of plaster on the surviving pier are too scanty to determine whether the same decorative motif continued also below the imposts (Fig. $\mathbf{4 b}$ ).

\section{MEANDERS}

Out of the numerous fragments of painted plaster which were found in the debris in the martyrion chapel ${ }^{7}$ the most significant group comprises pieces representing red, pink and black color fields and yellow bands decorated with a red meander. The same decorative motif is also preserved on several basalt ashlars (Fig. 5a). A characteristic feature visible on some of the larger surviving pieces is that the yellow, black and red color fields form acute and obtuse angles, as in hexagons or octagons (Fig. 5b). Each of these base colors has two tones - pink and dark red, light and dark yellow, black and gray. The sequence of these color fields varies: one example is decorated (from left to right) with a red and pink band, followed by a yellow field with meanders, a faded black band and a yellow field again. Another piece represents dark red and pink fields next to each other, a black stripe running along them followed by a yellow band with a red meander.

The excavators suggested that the meander motif occurred mostly on the southern and on the eastern wall. ${ }^{8}$ However, given the fact that this pattern also decorates the aforementioned blocks, which appear to have fallen from the northern wall (poorly preserved and the most incomplete as compared to the eastern and southern walls), one can presume that this decoration adorned all the walls and was one of the leading decorative patterns in the martyrion chapel. It is possible that it served as a kind of frame-motif surrounding other decorative fields.

\footnotetext{
${ }^{7}$ Młynarczyk, Burdajewicz 2002: Fig. 39.

${ }^{8}$ Młynarczyk, Burdajewicz 2003: 25.
} 

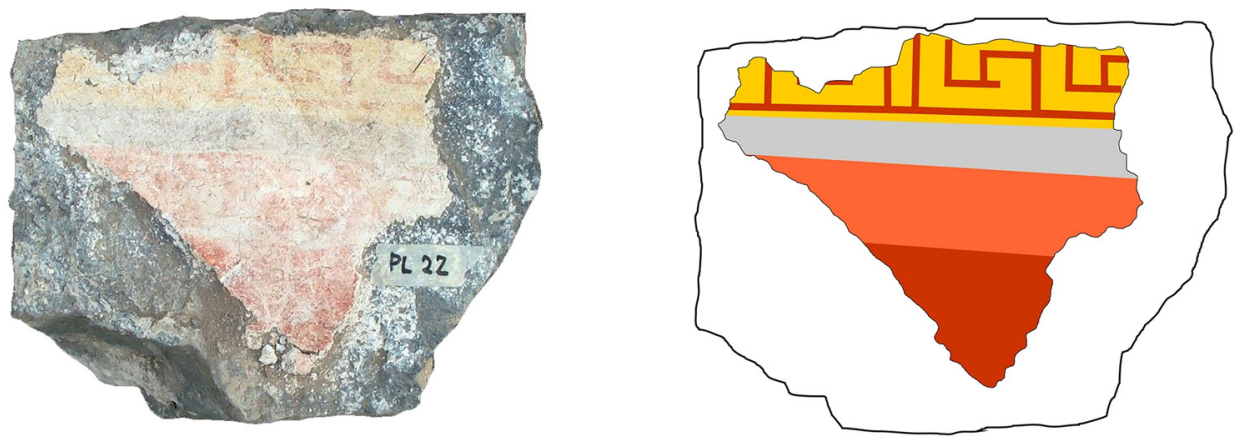

a

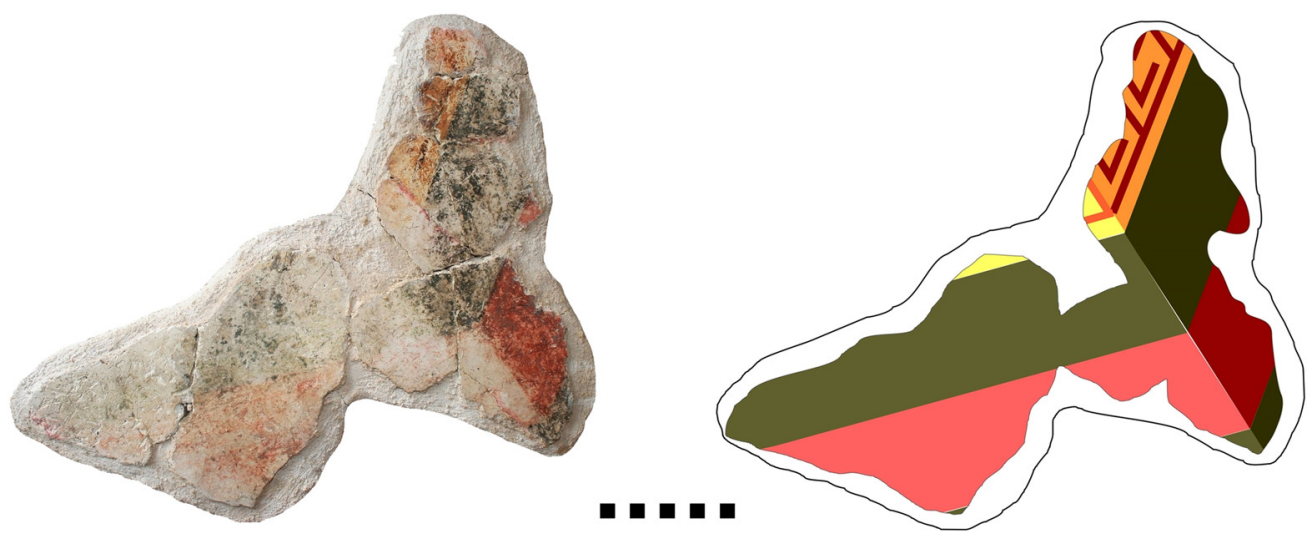

b

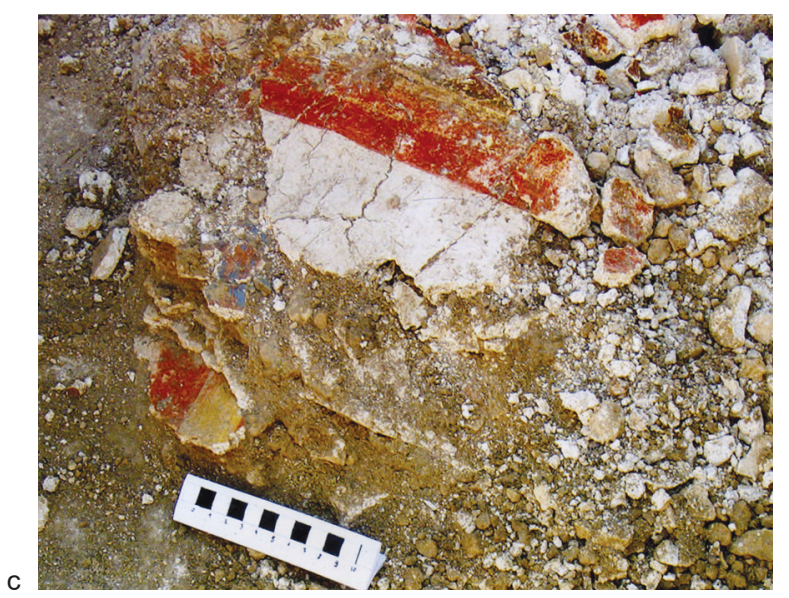

5a. One of the blocks from the martyrion retaining plaster decorated with the meander motif; b. reassembled fragments of plaster from the martyrion decorated with the meander motif; c. bright sheet of painted plaster (several hues of red, green, yellow, orange and blue colors) found at the foot of the eastern wall in the diakonikon (a-b. Phot. and drawing: J. Burdajewicz; c. Phot. J. Młynarczyk). 


\section{OTHER GEOMETRIC MOTIFS, SOLID COLORS AND COLOR COMBINATIONS}

Several fragments of white plaster decorated with black stripes about $3 \mathrm{~cm}$ wide were recovered from the debris across the chapel. One piece shows an intersection of a vertical and horizontal stripe. It is possible that these fragments represent either some kind of a grid or possibly a cross. Stripes of various colors appear on numerous small fragments of the paintings. They vary in thickness and combination of colors used, but they all run parallel to each other. The most common combinations of colors include red with black, green with yellow and red as well as green with black. Large quantities of pieces of plain red, orange, plain and pale yellow plaster fragments are present.

\section{Non-Ornamental Remains}

Some of the fragments of painted plaster found in the debris may suggest that the decoration of the chapel also featured some non-geometric, non-ornamental motifs, possibly figural representations. Noteworthy is the fact that the majority of them were found along the eastern wall of the martyrion. These pieces are too small to determine what kind of image they constituted, but two important features distinguish them from ornamental decorations: the style of the brushstrokes and lines, which appear unconstrained, irregular and of a free-hand character and a paint layer buildup, which lacks uniform, solid colors, but instead is characterized by superimposed layers of paint and soft transitions of tonality of colors.

One fragment of plaster, which was reassembled from eight small pieces, represents a round yellow shape surrounded by a blue color. Several other pieces appear as fragments of a red inscription placed against a blue background. The only other place in the church where traces of blue paint were found is the eastern wall of the diakonikon.

\section{THE DIAKONIKON}

Numerous fragments of wall plaster were found in situ on all walls, benches and elements of the arches dividing both rooms of the diakonikon, which is located in the southern wing of the church (Fig. 1). ${ }^{9}$ While no painted fragments were recorded by the excavators in the western room, the eastern room appears to had been adorned with painted decoration, at least on its eastern wall. Numerous colorful painted fragments were found in the eastern bay of the room, between the stone 'reliquary' and the eastern wall.

The most notable piece, unfortunately much damaged, was found under a collapsed limestone block. A sheet of brightly painted plaster was found folded into several layers and crushed to small pieces, probably having fallen from a significant height (Fig. 5c). A meticulous process of sorting the pieces in the lab resulted in a few reassembled fragments. The best preserved pieces display color bands of red, yellow and greenish brown; also remains of bright blue against a red background can be seen. Two of the most colorful

\footnotetext{
${ }^{9}$ Młynarczyk, Burdajewicz 2004: 71-72.
} 
pieces exhibit a thick paint layer buildup as compared to other fragments of paintings from the church, which could indicate that this decoration was not just a flat, repetitive pattern, but represented a more complex design. The use of blue pigment, not testified in other areas of the church except for a few fragments found in the martyrion chapel, may suggest that a depiction emphasizing a special significance of this area of the room was placed on the eastern wall of the diakonikon.

Besides the multi-colored fragments, a number of solid red fragments were recovered. Several pieces of plain white plasters with light red painted inscription were found, among which two fragments with letter alpha can be distinguished. A few fragments of white plaster with vertical brown stripes were found collapsed in the north-eastern corner of the room. ${ }^{10}$

\section{THE ATRIUM}

Very little plaster was found in the atrium, namely a few fragments of solid red color and a few fragments of what might have been a red inscription. These were found in front of the entrance to the southern aisle. ${ }^{11}$ However, a number of white and painted plasters of fairly high quality were found in the so-called wine cellar located below the floor level of the northern portico of the atrium. ${ }^{12}$ They were collected from the western part of the cellar, where the excavators noted a significant amount of collapsed stones and blocks as compared to the eastern part of the cellar. ${ }^{13}$ They represent a simple, free-hand in character, ornamental red decoration painted against a white background (Fig. 6). These pieces differ from those found in the church in terms of technique of execution, which appears to be of Hellenistic-Roman type (see below the 'Technical study' part).

\section{INTERPRETATION OF THE REMAINS}

Despite the great number of churches from the pre-iconoclastic period discovered in the southern Levant, very little is known of their interior wall decoration. Excavators and researchers usually focus on the mosaic floors which have often survived in good condition, whereas very little attention is given to the remains of painted plaster. Obviously it is usually the fragmentary state of the latter ones which discourages and hampers an in-depth art-historical study. ${ }^{14}$ As a result, only major findings are published, often without references to other similar discoveries. The main corpus of remains of wall paintings in the Early Byzantine churches in the southern Levant comprises a large, figural representation of Transfiguration in the southern church of Shivta; ${ }^{15}$ fragments of figural representations in

\footnotetext{
${ }^{10}$ Młynarczyk, Burdajewicz 2004: 53.

${ }^{11}$ Młynarczyk, Burdajewicz 2004: 60.

${ }^{12}$ Młynarczyk, Burdajewicz 2006: 52-57.

${ }^{13}$ Młynarczyk, Burdajewicz 2006: 53.

${ }^{14}$ However, cf. Vitto 1995.

${ }^{15}$ Woolley, Lawrence 1936; Figueras 2006.
} 


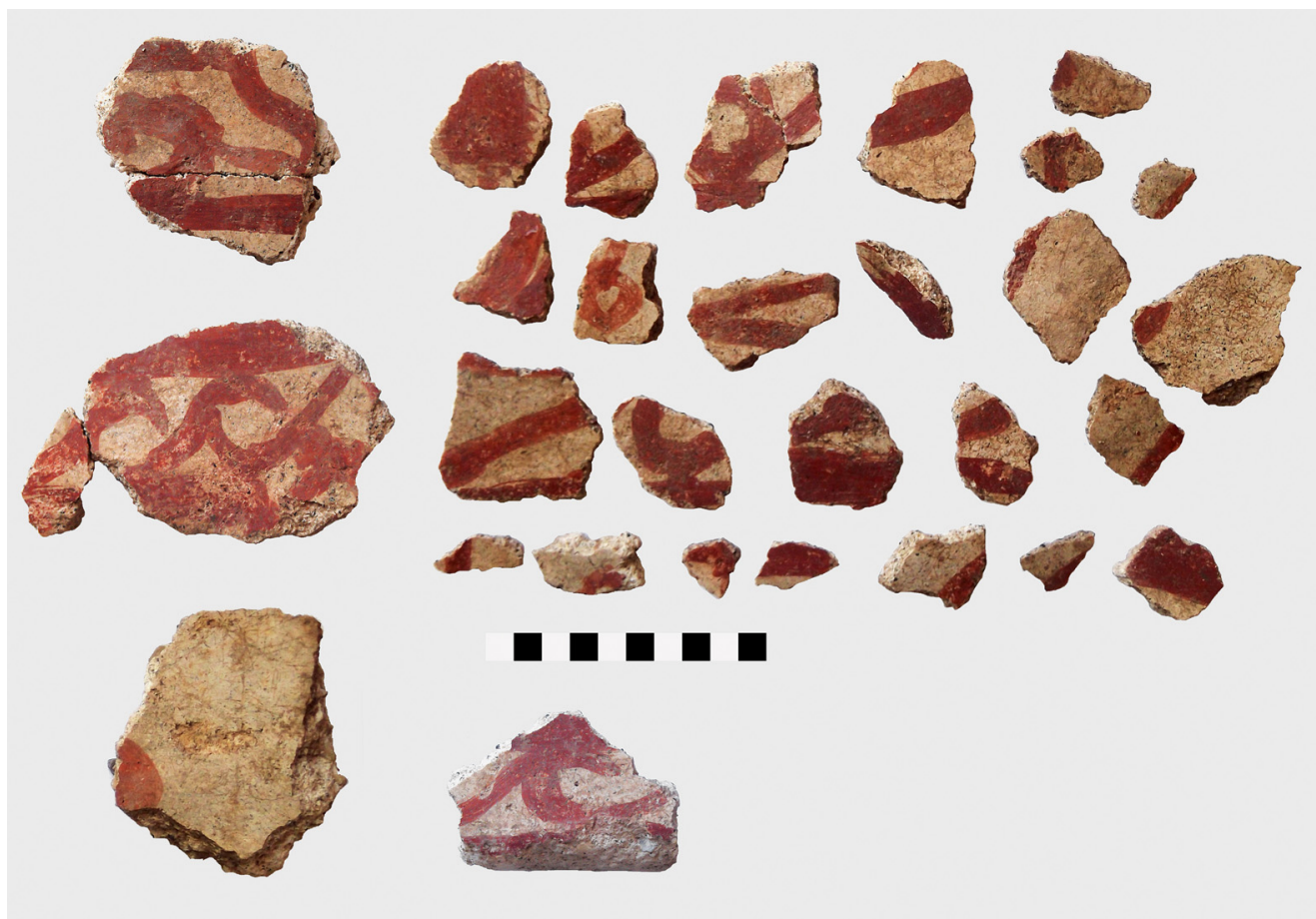

6. Fragments of the simple red geometric decoration found in the so-called wine cellar in the northern portico of the atrium (Phot. J. Burdajewicz).

the church of Priest Wa'il in Umm er-Rasas, ${ }^{16}$ in the Sanctuary of Lot in Deir Ain'Abata, ${ }^{17}$ and in the Northern Church in Rehovot-in-the-Negev; ${ }^{18}$ depictions of birds adoring a cross in church in Zahrani; ${ }^{19}$ geometric patterns found in the monastery of Khirbet ed-Deir ${ }^{20}$ and in the Chapel of the Miracle of the Swine in Kursi; ${ }^{21}$ an imitation of a hung textile in Ma'in; ${ }^{22}$ painted inscriptions in St. Stephen Church in Umm er-Rasas ${ }^{23}$ and in Petra. ${ }^{24}$ A large depiction of haloed figures was found in Caesarea Maritima. ${ }^{25}$

As in the case of the above-mentioned examples, the poor state of preservation of the wall paintings from the North-West Church at Hippos significantly limits studies on the interior mural decoration of the basilica. There are, however, several issues that can be

\footnotetext{
${ }_{16}$ Piccirillo 1993: 317-318, P1. V.

${ }^{17}$ Politis 2012: 369.

18 Tsafrir 1988: 64-67.

${ }^{19}$ Chéhab 1959: 91, P1. 42.

${ }^{20}$ Ben-Arieh 1999: 133-134, P1. XII.

${ }^{21}$ Tzaferis 1983: 49, P1. XIX.

${ }^{22}$ Piccirillo, Russan 1976: 61, P1. XXIV.

${ }^{23}$ Piccirillo, Alliata 1994: 264, P1. 26.

${ }^{24}$ Frösén, Sironen, Fiema 2008: 273-281, Pls 49-53.

${ }^{25}$ Avner 1999.
} 
addressed based on recovered finds. One of the questions to be asked is to what extent were the interior walls of the church painted? Given the fact that remains of painted wall plasters were found in all parts of the church $^{26}$ it can be assumed that the interior was largely decorated. The depictions on the walls, however, most likely did not start from the floor level, but from a certain height. This seems to be evidenced by remains of plain plaster in situ on the lower portions of the walls. Naturally, such a solution would have had a practical background - the paintings placed at a certain height above the floor are less exposed to damages. Only the columns in the basilica appear to be painted from the base to the top.

One decorative motif which could be interpreted with some certainty is the "rhombi and ovals' pattern adorning the archway into the martyrion. It is not clear whether it also ran on the faces of the piers, yet it appears more plausible that it decorated only the vault of the arch (Fig. 4a-b). A very similar motif, representing oval and rectangle 'jewels', can be found on wall mosaics decorating the churches from the pre-iconoclastic period both in the East and in the West. The church of Hosios David in Thessaloniki has such a motif decorating the conch of an apse with the representation of Christ (c. AD 540); ${ }^{27}$ wall mosaics running above the arches of the nave of the St. Demetrios church in Thessaloniki had a very similar decoration (the mosaics are now lost, known only from reproductions).$^{28}$ On the Italian peninsula, the 'jewels' motif can be found on the framing of imperial representation of Justinian in San Vitale in Ravenna (c. AD 540) ${ }^{29}$ as well as on the archway of the St. Venanzio chapel in the church of San Giovanni in Fonte on the Lateran in Rome $\left(\mathrm{AD}\right.$ 640-642) ${ }^{30}$ and on the triumphal arch of Santa Maria Maggiore (AD 432-440). ${ }^{31}$

It seems plausible that the 'rhombi and ovals' decoration of the martyrion archway was also meant to imitate precious stones adorning the entrance to the chapel, although it is naturally much simplified. It was painted against a yellow background in contrast to the red background which can be seen in the above-mentioned examples. Also the 'dabs' alternating with the 'rhombi and ovals' are red in the North-West Church, whereas in the other examples they are white, probably intended to imitate pearls. Similar 'jewels' decoration occasionally also appears on mosaic floors - for instance as framing of the figural mosaic in Houeidjit Halaoua (Syria) or on intercolumnia in St. Christopher church in Qabr Hiram (Lebanon). ${ }^{32}$

Another geometrical motif found in the martyrion, the 'meander', is somewhat more difficult to interpret. Numerous fragments preserved on the ashlars, as well as those found in

\footnotetext{
${ }^{26}$ With the exception of the southern aisle, but this may be related to the mechanics of the collapse during the earthquake which led to the destruction of the church: the walls fell northwards and because of that impact, the plaster had little chance of surviving.

${ }^{27}$ Spieser 1998: 64.

${ }^{28}$ Cormack 1969: 27, Pls 3, 7.

${ }^{29}$ Spieser 1998: 64.

${ }^{30}$ Mackie 1996: 1.

${ }^{31}$ Sieger 1987: 83.

${ }^{32}$ Donceel-Voûte 1988: 148, 417.
} 
debris suggest that this motif could have been the leading decorative pattern in the chapel. The following features of this motif can be observed:

- it consists of three basic colors - yellow with red meander, red and black;

- each of these three basic colors appears in two tonalities - lighter and darker, which may suggest some kind of light and shadow effect;

- these colors run along each other in bands, but they do not always have the same width and sequence;

- these color bands appear to turn in acute and obtuse angles.

The last feature could suggest an hexagonal or octagonal arrangement of patterns decorating the walls. Even though no parallels to such a representation have been found so far in wall paintings of the period, it is not unlikely that a hexagonal or octagonal grid could have adorned the walls. This kind of decoration can be found in fine stucco ornaments decorating the walls of Umayyad palaces of the early eighth century, such as in Qasr el-Heir el-Gharbi. ${ }^{33}$ Hexagons or octagons could have served as framing for some small decorative motifs placed within them.

An alternative interpretation of the fragments with meanders derives from the second feature listed above, that is the supposed 'light and shadow' effect. Such a visual effect is reminiscent of a 'folded rainbow' motif occurring in Mediaeval wall painting. One example can be found in the Coptic monastery of Macarius (Wadi el-Natrun; eleventh-twelfth century?). ${ }^{34}$ Another one appears on the intercolumnar arches of the St. Maria in Cosmedin church (date uncertain, possibly twelfth century). ${ }^{35}$ However, in each of these cases we can see that this decorative motif adorns arches, whereas in the case of the martyrion we are clearly dealing with flat pieces of plaster and vast surfaces.

Another type of decoration which allows for some interpretation are green strands painted on the columns of the North-West Church. The first possibility is that they were intended to imitate veins of white and green marble, concealing at the same time crude basalt of the shafts. Painted imitations of marbles were an inexpensive substitute for the real stone material, commonly executed in the Hellenistic-Roman period and after. Another possibility, however, is that the columns were decorated with vines entangling the shafts. Parallels of such decoration could be found on Constantine-era columns which used to support the ciborium over saint Peter's memoria in the Roman basilica of St. Peter. ${ }^{36}$ Portions of the flute-twisted shafts were intermitted with portions decorated with vines and putti. The motif of vines entangling a column appears also on a Coptic textile from the sixth century. ${ }^{37}$

The predominance of fragments of plaster decorated with geometrical motifs raises the question of whether the mural decoration of the church could have been aniconic. Identified

\footnotetext{
${ }^{33}$ Schlumberger 1939: P1. XLVII.

${ }^{34}$ Zibawi 2003: 154.

${ }^{35}$ Derbes 1995.

${ }^{36}$ Ward Perkins 1952.

${ }^{37}$ Bowersock 2006: 45.
} 
geometrical motifs seem to be very consistent with the decoration of the mosaic floors of the basilica, ${ }^{38}$ which are deprived of any images of nature, except for a few very simple depictions of fruit. Fruits, however, were usually considered rather a neutral geometrical motif than a representation of nature and were not a target of iconoclastic attacks.

Nevertheless, a few fragments from the martyrion chapel appear to represent non-ornamental and non-geometrical items. The unconstrained manner of execution of these paintings, alongside soft transitions of color tones, could be evidence of figural depictions. A piece with a fragment of a yellow round shape against a blue background may be a saint's halo. The presence of a blue color additionally points to the special significance of this depiction. Moreover, all these fragments were found along the eastern wall of the martyrion, where an image of a saint (or saints) would be highly appropriate. Unfortunately there are no wall paintings preserved in the main apse of the church where one could expect a monumental, figural representation, such as the one found in the Southern Church in Shivta. ${ }^{39}$

Despite the very scarce study material from the North-West Church, based on the analysis of surviving painted pieces, one can distinguish: 1. geometric motifs (various kinds of stripes found throughout the church, meanders and 'rhombi and ovals' in the martyrion); 2. possibly vegetal motifs (vines on the columns); 3. supposed figural representations (martyrion) and 4. painted inscriptions, whose small fragments were found throughout the church.

\section{TECHNICAL STUDY}

The art of wall painting in antiquity was brought to its artistic and technical pinnacle by the Romans. Guidelines for the artisans and artists are known to us thanks to Vitruvius, who explains in the VII ${ }^{\text {th }}$ Book of The Ten Books on Architecture the composition and characteristics of each of the substrate layers of a wall painting. ${ }^{40}$ Generally, the wall painting technique developed by the Romans could be characterized by the following features: application of several preparatory layers of mortars, each with specific filler-binder ratio and particle-size of the filler; the use of lime as binder, sometimes with pozzolanic additions; the decreasing thickness of subsequent layers leading to a very fine and smooth finished layer of plaster; execution of the paint layer in buon fresco technique ${ }^{41}$ and in some cases, application of final touches in a secco technique ${ }^{42}$ or in tempera. ${ }^{43}$

\footnotetext{
${ }^{38}$ Młynarczyk, Burdajewicz 2013: 203-204; Burdajewicz 2005: 61-64.

${ }^{39}$ Figueras 2006.

${ }^{40}$ Vitruvius, Ten Books 1914: VII, 3:5.

${ }^{41}$ In buon fresco paint layer is applied 'together with the last layer of plaster' (Vitruvius, Ten Books 1914: VII, 3:7-8). This means that the pigments mixed only with water are applied to wet plaster. During the chemical process of carbonation of the lime plaster, calcium hydroxide reacts with carbon dioxide from the air and forms calcium carbonate, which binds the pigments with the substrate, making the paint layer insoluble and durable.

${ }^{42}$ In a secco technique pigments are mixed with limewater and applied to relatively dry substrate layer. The secco technique has been also used by itself, both in earlier as in later centuries.

${ }^{43}$ Ling 1991: 198-211.
} 
There were no important technical innovations in the art of wall painting in the Eastern Mediterranean until the Middle Byzantine period (ninth-twelfth century), when the technique appears to had changed especially in relation to substrate layers. ${ }^{44}$ There are usually far fewer preparatory layers of mortar, and the mortars and plasters themselves contain small quantities of filler in ratio to the binder. Often, gypsum is used as a binder - by itself or in conjunction with lime. Additionally, an organic admixture, such as straw or animal hair, is widely present. This technique is often referred to as the Byzantine technique of wall painting. ${ }^{45}$

This shift in technique of execution and applied materials has not been tracked and analyzed in technical studies of the Eastern Mediterranean wall painting so far. The majority of information crucial for understanding the relations between particular chapters in history of wall painting can be derived from analysis of mortars and preparatory layers. By comparing their manner of execution, rendering and composition we may determine whether a wall painting was executed in a way more related to the Roman or Byzantine technique. Technical examinations of the Early Byzantine wall paintings are not, however, a common practice. This is partially due to the fact that they are often considered inferior to the sublime and sophisticated technique of execution of Roman wall paintings, and so they appear unworthy of analysis and deeper studies. In fact, only a few technical studies of wall paintings from the Early Byzantine period in the southern Levant have been carried out thus far; one can list here the analysis carried out on fragments of wall paintings from the Grotto of Annunciation in Nazareth, ${ }^{46}$ the examination of wall plasters in Jabal Harun (Petra) ${ }^{47}$ a thorough analysis of mortars and plasters from Umm el-Jimal ${ }^{48}$ and an unpublished MA thesis on Early Byzantine wall paintings from Caesarea. ${ }^{49} \mathrm{~A}$ wide variety of available analytical techniques alongside the lack of an established methodology for analysis of Byzantine wall plasters and paintings result in a spotty, incoherent body of knowledge.

\section{Execution of WALl PAINTINGS IN THE North-West Church}

\section{MACROSCOPIC OBSERVATIONS}

The plaster inside the church was either laid directly on the masonry or on top of one preparatory layer. The preparatory layer of mortar was applied only to portions of walls which were built of limestone or of mixed fieldstones and ashlars (both of limestone and basalt). Application of the preparatory layer of mortar allowed for sealing of the gaps between particular elements of the masonry and for evening out the surface of the wall. The preparatory layer has a varying thickness which ranges from 0.5 to $5 \mathrm{~cm}$. Based on

\footnotetext{
${ }^{44}$ Winfield 1968: 64-69.

${ }^{45}$ Winfield 1968.

${ }^{46}$ Capasso Carola 1969.

${ }^{47}$ Danelli 2008.

${ }^{48}$ Dunn, Rapp 2004.

${ }^{49}$ Linn 1996.
} 
macroscopic observations it is composed predominantly of binder with some admixture of small pebbles from the Sea of Galilee. Also fragments of small shells can be found in this layer. Often the mortar has a grayish color due to an admixture of carbonized organic material. It is porous and crumbly and generally in worse condition than the plaster layer.

The plaster layer was applied either on the preparatory layer of mortar or, as in the case of the basalt columns or portions of the walls which were built exclusively of tightly arranged neat basalt ashlars (for instance both apses), it was applied directly to the masonry. The plaster varies in thickness, but usually does not exceed $1 \mathrm{~cm}$. This layer is very porous, also with the predominance of binder over filler. The filler is not very evident during macroscopic examination. There is, however a significant amount of organic admixture. Voids left by disintegrated chopped straw are visible both on the plaster's surface as in the structure. Apart from that, the surface of the plaster is generally smooth, although with some chafe-marks, possibly left by the tool used to apply the material.

\section{MICROSCOPIC ANALYSIS}

In 2005 a number of samples of mortars and plasters collected throughout the church were analyzed at the Institute of Geology of the Adam Mickiewicz University in Poznan by Prof. Jacek Michniewicz and Dr. Danuta Michalska-Nawrocka. ${ }^{50}$ The analysis method comprised petrographic thin sections and XRD analysis. Seven of the samples were collected from patches of plaster surviving in situ: sample $6 \mathrm{~A}$ - plaster from the apse of the northern aisle; sample 8 - plaster of the western wall of the nave; sample 10 - plaster from the southern wall of the church, near the balustrade; sample 12 - plaster from the first column from the east of the southern aisle; sample 22 - plaster from the main apse; sample 66 - plaster from the eastern wall of the pastophorion; sample 70 - plaster from the pier between the nave and north aisle.

Samples 8, 10, 12 and 70 turned out to be composed of pure lime mixed with straw, which is testified by numerous elongated pores. Some of the pores are blocked due to crystallization of the carbonatious binder (i.e. sample 10). ${ }^{51}$ Sample 6A has a very similar composition of lime and straw, but additionally contains about $10-15 \%$ of aggregate belonging to a sandy fraction. The aggregate comprises grits of well-rounded basalt (0.5-1.5mm diameter), foraminiferous and massive limestone bits $(0.9-4.5 \mathrm{~mm})$, scarce quartz grains $(0.1-0.7 \mathrm{~mm})$, flints $(0.5-2.2 \mathrm{~mm})$, bivalve shells and crystalline limestone. ${ }^{52}$ Sample 22 is also similar to samples composed mainly of pure lime, but it contains an admixture of quartz sand in the amount of 5-8\%, too. Completely different in character is sample 66, coming from the eastern wall of the pastophorion, which is composed solely of gypsum. ${ }^{53}$

Since microscopic analysis did not confirm the presence of the uppermost, thin layer of plaster characteristic of buon fresco painting, it is plausible that the wall paintings were

\footnotetext{
${ }^{50}$ Michniewicz, Michalska-Nawrocka 2005.

${ }^{51}$ Michniewicz, Michalska-Nawrocka 2005: 91.

${ }^{52}$ Michniewicz, Michalska-Nawrocka 2005: 83.

${ }^{53}$ Michniewicz, Michalska-Nawrocka 2005: 88.
} 
executed in a secco technique. Also poor cohesion of the paint layers, which was observed in the case of the murals in the North-West Church, is a common issue with wall paintings a secco. Pigments analyzed with the use of spot tests revealed a simple palette of earth pigments based on iron oxides, such as green earth, ochre, iron red.

\section{PAINTINGS FROM THE 'WINE CELLAR'}

Fragments of ornamental paintings found in the so-called wine cellar in the northern portico of the atrium were not subject to microscopic analysis, but based solely on macroscopic observations one can note that their technique of execution significantly differs from murals found in the basilica. The substrate consists of three layers. The lowermost contains relatively large, multicolor pebbles, which appear to have come from the Sea of Galilee. This layer has an irregular thickness. On top of it is a layer of a uniform, hard and compact mortar, about $8 \mathrm{~mm}$ thick, which also contains a significant amount of aggregate, although of much smaller fraction. The grains are easily distinguishable by the naked eye, but the majority of them do not exceed $1 \mathrm{~mm}$ in length. There is also an insignificant admixture of small pebbles, c. $3 \mathrm{~mm}$ in length. There are no pores nor traces of organic admixture visible by the naked eye. The uppermost layer appears to be no more than $1 \mathrm{~mm}$ thick, containing very fine filler. The presence of a smooth and very thin uppermost layer of plaster as well as the very good condition of the paint layer may indicate that the painting was executed in a buon fresco technique on top of at least three, well-executed, layers of mortar. This technique and manner of execution appears Roman in character. It is plausible that these pieces may have survived on ashlars from a Roman-era building used for construction of the cellar.

\section{DISCUSSION}

Based on the macroscopic and microscopic observations, it could be noted that the wall paintings in the North-West Church were executed in a rather inexpensive manner, with the use of locally available materials and in a technique somewhat distant from the elaborate Roman techniques. The technique of execution of the painted plasters within the church appears to be quite consistent. It is characterized by the application of one layer of plaster, the use of pure lime mixed with straw and the exclusion of all but the slightest quantity of aggregates. Plasters with a small, yet distinctive quantity of aggregates can be found on the northern apse, which was added in a later phase of a church. The sample from the pastophorion, which also differs in composition, may be proof that the plaster in this room belong to a decoration from a different phase and building, but made their way into the church attached to the spolia. The painting technique is plausibly a secco.

It should be noted that there is no evidence of a second phase of plaster and wall painting. Normally, if a mural decoration deteriorates and has to be renovated or redone, the artists or workmen hatch the surface of the wall with hammers and apply a new layer (or layers) of mortar and plaster. Optionally, a layer of whitewash could also be applied, which does not require hatching the walls. In the North-West Church there were no traces of hatchings 
nor whitewash anywhere, which could lead to the conclusion that the surviving fragments of wall paintings belong to the first and the only phase of decoration of the church and were never renovated or redone, except for those adorning the northern apse, which belong to a second architectural phase of the church. ${ }^{54}$ In such a case, if we assume that the church was occupied from the sixth to mid-eighth century, the same wall paintings would have decorated the interior for about 250 years. Such situation is not improbable. It could also be one of the reasons why the wall paintings were found so deteriorated - possibly they were already in a poor condition at the moment of destruction of the church.

However, results of radiocarbon dating of one sample from the $\operatorname{church}^{55}$ carried out by Dr. Danuta Michalska, indicated the seventh-eighth century as the time of the execution, which is rather late if we assume that the church was built in the sixth century and that its terminus ante quem is $\mathrm{AD} 749$, the year of the great earthquake. Two explanations for such dating could be taken into consideration, unfortunately neither of them can be confirmed without radiocarbon dating of additional samples. The first possibility is that that the dated sample came from an area that was repaired in a late phase of the occupation of the church. The other option is that the wall painting decoration was indeed executed in the final decades of the church, after complete destruction (or intentional removal?) of earlier murals. The low quality of their technique of execution could be then related to the community's economic difficulties in the seventh and eighth centuries.

This basic study of the technique of execution of wall paintings in the North-West Church leaves many questions unanswered until more analyses is carried out. Nevertheless, technical studies of wall paintings should always be conducted in conjunction with art historical interpretation, as they can shed new light on such issues as chronology of the mural decoration in relation to architectural phases of the building or the economic condition of the community expressed by the quality of materials and of execution of the murals. Finally, investigating Early Byzantine wall paintings allows an expansion of the body of knowledge about the fascinating period of transition between the late Antique and Early Byzantine periods.

\section{Acknowledgments}

Project funded from the resources of the National Science Center granted based on the decision DEC-ODW/1/2012/07/B/HS3/02378.

\section{References}

Avner, T. 1999: Early Byzantine wall-paintings from Caesarea, [in:] Holum, K.G., Raban, A., Patrich, J. (Eds), Caesarea papers 2: Herod's temple, the provincial governor's Praetorium and granaries, the later harbor, a gold coin hoard, and other studies, JRA-Suppl. 35, Portsmouth, 108-128

\footnotetext{
${ }^{54}$ Młynarczyk, Burdajewicz 2004: 69.

${ }^{55}$ Michalska-Nawrocka 2005: 95.
} 
Ben-Arieh, R. 1999: The Frescoes, [in:] Hirschfeld, Y., The Early Byzantine Monastery at Khirbet ed-Deir in the Judean Desert: The Excavations in 1981-1987, Qedem $38,133-134$

Bowersock, G.W. 2006: Mosaics as history: the Near East from late antiquity to Islam, Cambridge, Mass.

Burdajewicz, J. 2005: Patterns of the mosaic pavement in the nave of the NWC, [in:] Segal, A. et al., Hippos-Sussita, Sixth Season of Excavations (July 2005), Haifa, 61-64

Capasso Carola, A. 1969: Esami di frammenti di intonaci provenienti dalla grotta della Annunzazione di Nazareth, LibAnn XIX, 168-191

Chéhab, M. 1959: Mosaïques du Liban, Bulletin du Musee de Beyrouth XV, Paris

Cormack, R.S. 1969: The Mosaic Decoration of S. Demetrios, Thessaloniki: A Re-Examination in the Light of the Drawings of W. S. George, ABSA 64, 17-52

Danelli, Ch. 2008: The Analysis of Wall Plaster at Jabal Hārūn, [in:] Fiema, Z.T., Frösén, J., (Eds), Petra - The Mountain of Aaron. The Finnish Archaeological Project in Jordan I: The Church and the Chapel, Helsinki, 405-419

Derbes, A. 1995: Crusading Ideology and the Frescoes of S. Maria in Cosmedin, ArtBull $77 / 3,460-478$

Donceel-Voûte, P. 1988: Les pavements des églises byzantines de Syrie et du Liban: décor, archéologie et liturgie, Publications d'histoire de l'art et d-archéologie de L'Université Catholique de Louvain LXIX, Louvain-la-Neuve

Dunn, E., Rapp, G. 2004: Characterization of Mortars and Pozzolanic Materials from Umm el-Jimal, Studies in Conservation 49/3, 145-160

Figueras, P. 2006: Remains of a Mural Painting of the Transfiguration in the Southern Church of Sobata (Shivta), ARAM Period. 18-19, 127-151

Frösén, J., Sironen, E., Fiema, Z.T. 2008: Greek Inscriptions from the Church and the Chapel, [in:] Fiema, Z.T., Frösén, J. (Eds), Petra - The Mountain of Aaron. The Finnish Archaeological Project in Jordan I: The Church and the Chapel, 273-281

Ling, R. 1991: Roman Painting, Cambridge

Linn, R. 1996: Scientific Investigation of Roman and Early Byzantine Wall Paintings in Caesarea, unpublished MA thesis, University of London, London

Mackie, G. 1996: The San Venanzio Chapel in Rome and the Martyr Shrine Sequence, RACAR: revue d'art canadienne / Canadian Art Review 23/1-2, 1-13

Michalska-Nawrocka, D. 2005: Geoarcheological studies and radiocarbon determination from Hippos, [in:] Segal, A. et al., Hippos-Sussita. Sixth Season of Excavations (July 2005), Haifa, 92-98

Michniewicz, J., Michalska-Nawrocka, D. 2005: Petrography of the plasters from Hippos, [in:] Segal, A. et al., Hippos-Sussita. Sixth Season of Excavations (July 2005), Haifa, 82-91

Młynarczyk, J., Burdajewicz, M. 2001: North-west Church Complex, [in:] Segal, A., Młynarczyk, J., Burdajewicz, M., Hippos (Sussita). Second Season of Excavations, July 2001, Haifa, 7-13 
Młynarczyk, J., Burdajewicz, M. 2002: Exploration of the North-West Church Complex [areas NWC and OPB] in 2002, [in:] Segal, A. et al., Hippos (Sussita). Third Season of Excavations, July 2002, Haifa, 15-28

Młynarczyk, J., Burdajewicz, M. 2003: North-West Church (NWC) Complex, [in:] Segal, A. et al., Hippos-Sussita. Fourth Season of Excavations, June-July 2003, Haifa, 24-33

Młynarczyk, J., Burdajewicz, M. 2004: The North-West Church (NWC), [in:] Segal, A. et al., Hippos-Sussita. Fifth Season of Excavations, September-October 2004 and Summary of All Five Seasons (2000-2004), Haifa, 52-72

Młynarczyk, J., Burdajewicz, M. 2006: North-West Church Complex (NWC), [in:] Segal, A. et al., Hippos-Sussita. Seventh Season of Excavations, July 2006, Haifa, 47-59 Młynarczyk, J., Burdajewicz, M. 2013: The Northwest Church Complex, [in:] Segal A. et al., Hippos-Sussita of the Decapolis. The First Twelve Seasons of Excavations 2000-2011 I, 194-217

Piccirillo, M. 1993: La Chiesa del prete Wa'il a Umm al-Rasas - Kastron Mefaa in Giordania, [in:] Manns, F., Alliata, E. (Eds), Early Christianity in Context. Monuments and Documents, Studium Biblicum Franciscanum - Collectio Maior 38, Jerusalem, 313-334

Piccirillo, M., Alliata, E. 1994: Umm al-Rasas, Mayfa'ah, Gli Scavi del Complesso di Santo Stefano, Studium Biblicum Franciscanum - Collectio Maior 28, Jerusalem

Piccirillo, M., Russan, M. 1976: A Byzantine Church at ed-Deir (Ma'in), Annual of the Department of Antiquities of Jordan XXI, 61-70

Politis, K.D. 2012: Sanctuary of Lot at Deir 'Ain 'Abata in Jordan: Excavations 1988-2003, Amman

Rądkowska, J. 2004: Mural remains from the martyrion chapel in the North-West Church, [in:] Segal, A. et al., Hippos-Sussita. Fifth Season of Excavations, September-October 2004 and Summary of All Five Seasons (2000-2004), Haifa, 76-79

Schlumberger, D. 1939: Les fouilles de Qasr el-Heir el-Gharbi (1936-1938), Rapport Préliminaire (Deuxième article), Syria XX/4, 324-373

Sieger, J.D. 1987: Visual Metaphor as Theology: Leo the Great's Sermons on the Incarnation and the Arch Mosaics at S. Maria Maggiore, Gesta 26/2, 83-91

Spieser, J.-M. 1998: The Representation of Christ in the Apses of Early Christian Churches, Gesta 37/1, 63-73

Tsafrir, Y. 1988: The Northern Church, [in:] Tsafrir, Y., Patrich, J., Rosenthal-Heginbottom, R., Hershkovitz, I., Nevo, Y.D. (Eds), Excavations at Rehovot-in-the-Negev I: The Northern Church, Qedem 25, Jerusalem, 22-77

Tzaferis, V. 1983: The Excavations of Kursi-Gergesa, 'Atiqot 16, 1-65

Vitruvius, Ten Books 1914: Vitruvius, The Ten Books on Architecture, transl. M. Hicky Morgan, Cambridge, Mass. 1914

Vitto, F. 1995: The Interior Decoration of Palestinian Churches and Synagogues, [in:] Efthymiadis, S., Rapp, C., Tsougarakis, D. (Eds), Bosphorus: essays in honor of Cyril Mango, ByzForsch 21, Amsterdam, 283-300 
Ward Perkins, J.B. 1952: The Shrine of St. Peter and Its Twelve Spiral Columns, JRS 42, 21-33

Winfield, D.C. 1968: Middle and Later Byzantine Wall Painting Methods. A Comparative Study, DOP 22, 61-139

Woolley, C.L., Lawrence, T.E. 1936: The Wilderness of Zin, New York

Zibawi, M. 2003: Images de l'Égypte chrétienne: iconologie copte, Paris-Milano 


\section{ÉTUDES et TRAVAUX XXX / 2017}

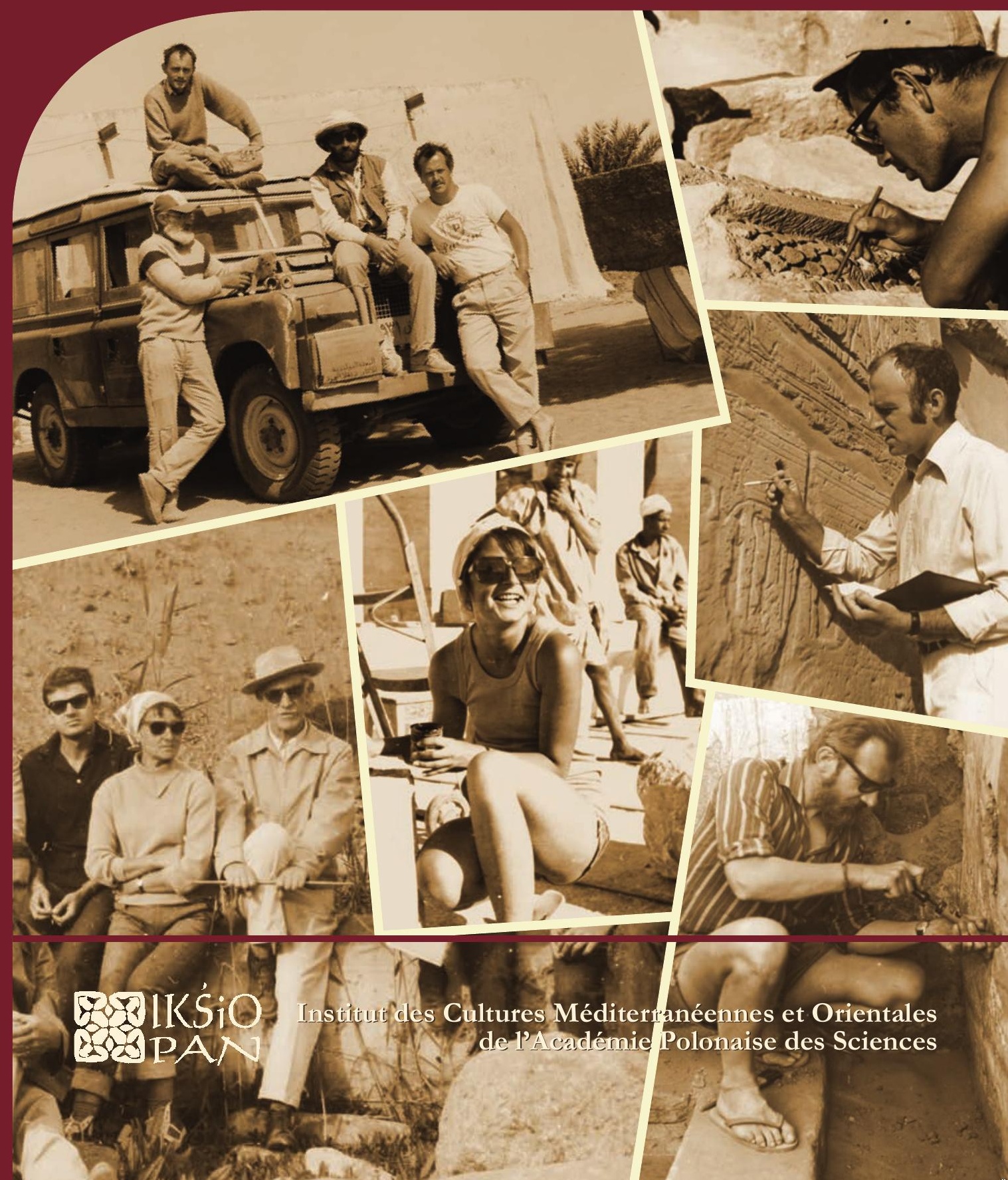




\title{
COMITÉ DE RÉDACTION SCIENTIFIQUE
}

Maciej Makowski - rédacteur en chef

Jadwiga Iwaszczuk - rédacteur et sécretaire de la rédaction

Mariusz Drzewiecki - rédacteur

Maciej G. Witkowski - rédacteur

\section{CONSEIL SCIENTIFIQUE DU JOURNAL}

M. Kobusiewicz (IAE PAS, Warszawa), E. Laskowska-Kusztal (IMOC PAS, Warszawa),

D. Michaelides (University of Cyprus, Nicosia),

J.Ch. Moretti (IRAA-MOM, Université de Lyon 2/CNRS),

D. Raue (Ägyptisches Museum der Universität Leipzig), P. Reynolds (ICREA, Barcelona),

D. Welsby (British Museum, London)

\section{COMITÉ SCIENTIFIQUE DE LECTURE}

J. Holaubek (Institut für Ägyptologie, Wien), S. Ikram (AUC, Cairo),

K. Innemée (Universiteit Leiden), J. McKenzie (Faculty of Oriental Studies, University of Oxford),

N. Strudwick (University of Cambridge), A. Loprieno-Gnirs (Universität Basel),

Ch.E. Loeben (Museen für Kulturgeschichte, Hannover), Y. Tristant (Macquarie University, Sydney),

V.W.J. van Gerven Oei (University of Aberdeen), A. Peignard-Giros (HiSoMA-MOM, Université de Lyon 2/CNRS), J.A. Ostrowski, E. Papuci-Władyka, J. Śliwa (IA JU, Kraków), R. Czerner (WUST, Wrocław), A. Ćwiek (IA AMU, Poznań), M. Wiewióra (IA NCU, Toruń), K. Domżalski

(IAE PAS, Warszawa), K.O. Kuraszkiewicz (DE FOS UW), M. Barwik, P. Bieliński, P. Dyczek, W. Godlewski, D. Ławecka, S. Rzepka, J. Żelazowski, M. Gawlikowski, J. Młynarczyk, A. Niwiński, T. Sarnowski, D. Szeląg, T. Waliszewski (IA UW, Warszawa)

\section{RÉDACTEUR THÉMATIQUE DU VOLUME \\ Barbara Lichocka}

\author{
AIDE RÉDACTION TECHNIQUE \\ Dorota Dobrzyńska, Mariusz Drzewiecki
}

REVUE DES TEXTES ANGLAIS

Jo Harper 
ÉTUDES et TRAVAUX XXX 
INSTYTUT KULTUR ŚRÓDZIEMNOMORSKICH I ORIENTALNYCH POLSKIEJ AKADEMII NAUK

\section{STUDIA i PRACE}

XXX

\section{Ro IKŚSiO \\ ESA PAN}

WARSZAWA

2017 
INSTITUT DES CULTURES MÉDITERRANÉENNES ET ORIENTALES DE L'ACADÉMIE POLONAISE DES SCIENCES

\section{ÉTUDES et TRAVAUX}

XXX

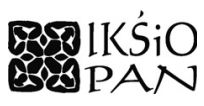

VARSOVIE

2017 
Publication scientifique financée dans le cadre du programme du Ministre de la Science et de l'Éducation Supérieure

« Programme National de Développement de l’Humanistique » pour les années 2016-2021 (projet no 3bH 150099 83)

\title{
HARODOWY PROGRAM ROZWOJU HUMANISTYKI
}

\author{
Copyright (C) \\ Instytut Kultur Śródziemnomorskich i Orientalnych PAN \\ et les Auteurs \\ Warszawa 2017
}

\author{
ISSN 2084-6762 \\ (avant $2011: 0079-3566$ ) \\ e-ISSN 2449-9579 \\ Version première en papier, imprimée en Pologne - 150 copies \\ Version électronique accessible sur \\ http://www.etudesettravaux.iksiopan.pl
}

Édition: Polskie Towarzystwo Historyczne et Wydawnictwo Neriton, Warszawa

Conception générale de couverture : J. Iwaszczuk

Photos de couverture : En haut, à gauche. Vieille Dongola 1991, S. Jakobielski

(debout à gauche), K. Pluskota (debout à droite), B. Żurawski (assis sur le camion)

et P. Wierzbicki (assis sur le camion) (de la collection de B. Żurawski)

En haut, à droite. Palmyre 1964, M. Marciniak au travail (phot. A. Dziewanowski)

Au centre. E. Laskowska-Kusztal au travail (de la collection de E. Laskowska-Kusztal)

En bas, à gauche. Tell Atrib 1962 ; de gauche : T. Biniewski, M. Marciniak, K. Kołodziejczyk,

K. Michałowski, A. Ostrasz, S. Jakobielski et S. Jasiewicz devant eux

(de la collection de IKŚSiO PAN).

En bas, à droite. Vieille Dongola 1976, S. Jakobielski nettoyant le mur (phot. M. Steinborn).

Au centre, à droite, K. Myśliwiec en train des travaux de documentation (de la collection de IKŚiO PAN) 


\section{Table des matières}

BARBARA LICHOCKA

Ergon agathon

Hartwig Altenmüller

$\mathrm{Zu}$ den Feindbildern auf den Zauberstäben des Mittleren Reiches und der Zweiten

Zwischenzeit

Nathalie Beaux

Des $m s w n s w$ de Thoutmosis III à Deir el-Bahari

Briant Bohleke, Nigel Strudwick

A Label for Opening of the Mouth Implements from the Burial of Senneferi (TT99)

and Remarks on the Ritual

Rosa Maria Bonacasa Carra, Nicola Bonacasa

Nuovi dati sugli edifici termali di Sabratha

EDWARD BROVARSKI

A Fragmentary Carrying Chair Scene in Salt Lake City, Utah

Julia Burdajewicz

Wall Painting Decoration from the North-West Church in Hippos-Sussita

of the Decapolis

Mariusz BURDAJEWICZ

From Pagan Temple to Church in Late Antiquity Palestine. A View from

Hippos-Sussita

MAREK ChlodNicki

Early Dynastic Bead Workshops at the Central Kom of Tell el-Farkha.

Patryk ChudziK, Mariusz Caban

Observations on the Architecture of the Tomb of Horhotep in Western Thebes

Krzysztof M. Cialowicz

New Discoveries at Tell el-Farkha and the Beginnings of the Egyptian State.

Amr EL-TiebI

Four Wooden New Kingdom Female Statuettes in the Egyptian Museum, Cairo 


\section{Naguib KanaWATI}

Ritual Marriage Alliances and Consolidation of Power in Middle Egypt during the Middle Kingdom

Adam Łajtar, Jolanta Mlynarczyk

A Faction Acclamation Incised on a Pithos Found Near the North-West Church at Hippos (Sussita)

Adam ŁaJTAR, Grzegorz OchaŁa

Two Private Prayers in Wall Inscriptions in the Faras Cathedral

Adam Łajtar, Anna Poludnikiewicz

Medicinal Vessels from Tell Atrib (Egypt)

JaCeK Michniewicz, Jolanta MlynarczyK

Petrographic Variability of the Fabrics of Wine Jars from Sha'ar-Ha Amakim as a Reflection of Differences in Their Provenance and Chronology

Iwona ModrzewsKa-PianetTI

Les importations d'amphores Dressel 20 en Gaule Cisalpine

Arthur SEgal

Samaria-Sebaste. Portrait of a polis in the Heart of Samaria 409

JOACHIM ŚLIWA

The Motif of a 'Blind Harper' in an Unexpected Place

MONIKA WIĘCH

Searching for the Kitchen in the Early Roman Phase of the 'Hellenistic' House at Nea Paphos (Cyprus)

Abréviations 
THE VOLUME IS PUBLISHED TO CELEBRATE

THE $60^{\text {TH }}$ ANNIVERSARY

OF THE ESTABLISHMENT OF

THE RESEARCH CENTRE FOR MEDITERRANEAN ARCHAEOLOGY POLISH ACADEMY OF SCIENCES

FOUNDED IN 1956

WHOSE MISSION IS CONTINUED BY

THE INSTITUTE OF MEDITERRANEAN AND ORIENTAL CULTURES

OF THE POLISH ACADEMY OF SCIENCES 